\title{
Bargains Old and New: Multinational Corporations in Global Governance
}

\author{
DAVID L. LEVY $\dagger^{*} \&$ ASEEM PRAKASH $\$$ \\ $\dagger$ University of Massachusetts, Boston, $\ddagger$ University of Washington-Seattle
}

\begin{abstract}
This paper outlines an approach for understanding the role of multinational corporations (MNCs) in global governance. We develop a typology of regime types with two dimensions, the goal of the regime, which can be market enabling or regulatory, and the location of authority, which can be national, regional, or international, with public and private elements. MNCs tend to support the creation of market enabling regimes at the international level, and prefer to keep social or environmental regulation under national or private authority. However, these are only generalizations and MNCs develop preferences based on their relative influence in various arenas, the costs of political participation, and competitive considerations. We argue that institutions of global governance represent the outcome of a series of negotiations among corporations, states, and non-state actors. The preferences and power of MNCs vary across issues and sectors, and from one negotiating forum to another, accounting for the uneven and fragmented nature of the resulting system. Our approach differs from the traditional FDI bargaining framework in that it recognizes the multi-party nature of negotiations and multiple sources of power. Moreover, the complexity and dynamic nature of the process results in a somewhat indeterminate process.
\end{abstract}

\section{Introduction}

International regimes are a critical element of global governance. Regime theory has been widely criticized for its state centered approach, and increasing attention has been paid to domestic political factors and non-state actors, especially non-governmental organizations (NGOs). ${ }^{1}$ Very few, however, have examined regimes from the perspective of multinational corporations (MNCs), despite their critical influence in the international political economy. Drawing on international business and international political economy literatures, this paper outlines an approach to analyzing regimes from the perspective of MNCs. In doing so, we build upon the work of Raymond Vernon, whose Product Life Cycle theory of trade and investment moved the conceptual spotlight from nations to corporate strategy. ${ }^{2}$ In this tradition, we seek to understand the formation and content of regimes of international governance in terms of the interests and strategies of MNCs.

\footnotetext{
* Correspondence: David L. Levy, Professor, Department of Management, University of Massachusetts, 100 Morrissey Boulevard, Boston, MA 02125, USA. Tel: (617) 287-7860; E-mail: David.Levy@umb.edu

1. Higgott, Underhill and Bieler (1999); Strange (1996).

2. Vernon (1966).
} 
The increasing internationalization of production and markets over the last several decades, however uneven and incomplete, has been accompanied by the emergence of various forms of supranational/global governance, both at regional and international levels. From regional trade agreements to international environmental treaties, we are witnessing the emergence of multilateral institutions and sources of authority that increasingly influence the operations of multinational corporations (MNCs). Even in the absence of a supranational authority, negotiations among governments, firms and NGOs are leading to the establishment of regimes-rules, norms, codes of conduct, and standards - that constrain, facilitate, and shape MNCs' market behaviors. ${ }^{3}$

In recent debates, three arguments have frequently been made, often implicitly, concerning the power and preferences of MNCs in relation to institutions of global governance. The first argument is that the power of MNCs to shape outcomes has increased in relation to governments and other societal actors (the decline of the Westphalian state hypothesis). The second is that MNCs prefer to see regulatory authority shift away from national governments and toward supranational institutions, and that this shift has, indeed, been underway (the decline of the regulatory state hypothesis). The third is that, as part of the MNC agenda, supranational regimes facilitate the lowering of regulatory standards across jurisdictions, particularly in the areas of labor, environment, health and safety (the race-to-the bottom hypothesis).

This paper critically examines these arguments. We find that MNCs are not always seeking the extension of supranational regimes to lower regulatory standards; indeed they sometimes seek to enhance domestic governments' capacities to establish stringent regulations. Moreover, the complexity and dynamic nature of regime bargaining processes, combined with strategic behaviors by MNCs, NGOs, and governments, lends a degree of indeterminacy to regime formation processes. Consequently, MNCs' goals and interests vary across issues and sectors, and MNCs do not always achieve what they want. We explore the preferences of MNCs through a new typology of regimes. We identify key elements of a new version of the MNC-state bargaining theory, which serves to shed light on the ability of MNCs to secure the type of regime they desire. The paper thus examines MNCs' preferences and power regarding international regimes.

\section{A typology of regimes}

Regime theory, which has attempted to explain the emergence and diversity of supranational institutions of governance, could usefully inform our understanding of the role of MNCs in the structuring of international governance. ${ }^{4}$ Key themes in this literature relate to the conditions under which regimes arise, their function, and how they affect collective outcomes. Developed to explain the institutionalized mechanisms of international co-operation within an anarchic world, regime theory has come to employ a notion of governance that is similar

3. Haggard and Simmons (1987); Keohane (1983).

4. Young (1994). 
to that used by students of domestic politics. In his widely used definition, Krasner posits that regimes are "implicit or explicit principles, norms and decision-making procedures around which actors' expectations converge in a given area of international relations." ${ }^{5}$ In a similar vein, Keohane has defined regimes as "persistent and connected sets of rules and practices that prescribe behavioral roles, constrain activity, and shape expectations." Notable in these and other definitions is the recognition of cognitive and normative dimensions of ordered international conduct, and their abstraction from specific organizational forms. Young emphasizes this distinction between governance, "in the sense of rules of the game that serve to define social practices, assign roles, and guide interactions," personnel, budgets, equipment, and more often than not, legal personality." Much of regime theory has concentrated on describing the processes by which states agree to give up sovereignty in policy areas through the implementation of international agreements. In this paper, we propose that MNCs are key actors in the formation of governance regimes and that corporate strategies play an important role in the trajectory of regime development. In particular, David Baron has argued that firms need to develop an integrated strategy encompassing both their market and non-market environments. ${ }^{9}$ Specifically, firms need to examine how a regime bestows benefits or imposes costs in relation to their market competitors, and consider how a regime influences the balance of power in relation to non-market actors such as NGOs.

Negotiations over institutions of governance give rise to regimes that vary in two key dimensions that matter to MNCs, regime purpose and regime authority structure. The first dimension relates to whether the primary objective of the regime is either market liberalization by expanding market opportunities and reducing transaction costs, or the imposition of regulatory constraints for environmental, social, or other purposes. ${ }^{10}$ Firms are generally viewed as supportive of market-enabling regimes, such as the General Agreement on Tariffs and Trade (GATT) and now, the World Trade Organization (WTO), under whose auspices the liberalization of international trade has proceeded apace during the last five decades. Of course, creating opportunities for some firms may present threats for others. Typically, firms in protected or inefficient sectors oppose trade liberalization, with the recent campaign by the US textile industry against relaxing the Multi-Fiber Agreement round being a case in point. Social and environmental regulation, by contrast, is generally viewed as imposing constraints on business, restricting market opportunities for MNCs and creating costly compliance requirements. For example, the Basle convention restricted international trade in hazardous waste and the Montreal Protocol phased out production and trade of ozone-depleting chemicals. While many

\footnotetext{
5. Krasner (1983) p. 2.

6. Keohane, Haas and Levy (1993).

7. Young (1994) p. 4.

8. Young (1994) p. 15.

9. Baron (1995).

10. Levy and Egan (2000) refer to these regime types as "market-enabling" and "regulatory".
} 
David L. Levy \& Aseem Prakash

TABLE 1. New bargains: a typology of regimes

\begin{tabular}{lll}
\hline \multirow{2}{*}{ Location of authority } & \multicolumn{2}{c}{ Regime purpose } \\
\cline { 2 - 3 } Domestic & Market enabling & Regulatory \\
\hline \multirow{2}{*}{ Supranational } & Trade-related intellectual & ISO 14001, \\
& property rights & Forest Stewardship Council \\
& World Trade Organization & Montreal Protocol on \\
& & Ozone Depleting Gases \\
& & Nuclear Non-Proliferation Treaty \\
\hline
\end{tabular}

firms are expected to oppose such regulatory regimes, particular competitive concerns can alter the situation.

The second dimension of our regime typology pertains to the regime's authority structure, specifically the location of authority for monitoring compliance and enforcement of regime provisions. In particular, we are interested in the location of authority that monitors and enforces rules influencing MNCs' sourcing, operations, sales, and profitability. This authority can be located at the national or supranational (regional or international) levels. Furthermore, this authority can be vested with state or private actors. Authority structures can also be complex and hybrid. Public law may provide for private monitoring and enforcement. To illustrate, the provision of private attorneys-general in the American environmental jurisprudence enables private actors to prosecute firms for alleged environmental violations and even recover costs of litigation. International environmental regimes generally have some monitoring mechanisms under the auspices of supranational institutions, but much of their implementation and enforcement is at the national level.

Together, the two attributes, regime purpose and regime authority structure, yield a matrix of four analytical regime types: market enabling-domestic, market enabling-supranational, regulatory-domestic, and regulatory-supranational (Table $1)$.

We briefly discuss MNCs' preferences for these regime types below. Our key argument is that to understand MNCs' support or opposition for a particular regime type, one has to examine $\mathrm{MNCs}$ ' perceptions of their relative influence versus other actors across governance arenas as well as the competitive implications of specific regimes.

\section{Regime purpose}

The WTO and the now-stalled Multilateral Agreement on Investment (MAI) are examples of market-enabling regimes, which tend to reduce transaction costs and provide collective goods important to MNCs, such as standards, multilateral recognition, and enforcement of Intellectual Property Rights (IPRs). As Lake has remarked concerning the MAI and WTO, "governments are constrained from 
exercising sovereign powers but no higher authorities are created-in each case, further widening the private sphere."11

On the face of it, MNCs should support market-enabling regimes. However, while some sectors, such as banking, pharmaceuticals, agriculture, and electronics, have been strong supporters of multilateral market-enabling agreements, others, notably the automobile industry and some consumer appliance firms, have preferred a strategy of regional integration, such as that offered by NAFTA. This regional approach offers companies a route to reconciling the potentially conflicting objectives of rationalizing production and implementing lean production, ${ }^{12}$ while providing a degree of protection against European and Japanese competitors. ${ }^{13}$ Moreover, firms operating in highly regulated markets sometimes oppose the dismantling of regulations. ${ }^{14}$ The railroad and trucking industries are classic examples of how regulations can serve as a barrier to entry. ${ }^{15}$

MNCs may also oppose the expansion of a market-enabling regime if it puts them at a competitive disadvantage. The recent dispute between the European Union and the United States over China's entry to the WTO included the proposed rules for entering China's insurance industry. China wanted to require foreign insurance companies to have joint ventures with local companies. The American insurance giant, American Insurance Group (AIG), however, already had a presence in China and was exempted from this requirement. European MNCs feared that this provided a competitive advantage to AIG, so they lobbied their governments to hold up China's entry in the WTO till rules were modified to provide a more level playing field. ${ }^{16}$

Regulatory regimes are primarily designed to impose constraints on aspects of corporate behavior, including sourcing, production, sales, and distribution of profits. These types of regimes typically address the social costs of corporate operations and provide collective goods, such as environmental improvements and worker safety. Examples include the 2000 Cartegena Protocol on Biosafety, the 1997 Kyoto Protocol to reduce emissions of greenhouse gases, and various proposals for codes of conduct regarding labor standards and the environment.

Many regimes have a complex, hybrid nature, which requires decomposition for the sake of analysis. Regulatory regimes whose primary purpose is to constrain MNC behavior may generate new markets that did not previously exist. For example, the Kyoto protocol, which regulates the emission of carbon dioxide and other greenhouse gases, will establish global markets for carbon trading among firms and countries. Such markets, which create opportunities for companies to invest in low-emission technologies, have not existed before because the global atmosphere has been treated as an open access resource. Regulatory regimes can also facilitate trade through the harmonization of technical and environmental standards. ${ }^{17}$

\footnotetext{
11. Lake (1999) p. 47.

12. Levy (1997).

13. Eden and Molot (1993).

14. Stigler (1971).

15. Kolko (1963).

16. Chandler (2001).

17. Haufler (2001).
} 
Market enabling regimes frequently have regulatory features. Regional tradeliberalization agreements such as the European Union and NAFTA both have market-limiting components advocated by specific sectors; the local-content requirements for the auto industry in NAFTA are a case in point. ${ }^{18}$ The NAFTA side agreements on labor and the environment, though generally viewed as weak, represent regulatory elements adopted to accommodate social pressures. The governance of intellectual property rights (IPRs) is another example of a complex, hybrid regime. The enforcement of IPRs can represent a form of protectionism for MNCs that constrains competition, though the establishment of property rights also has a market-enabling dimension by encouraging investment in new technologies and trade in resultant products. For example, a key factor in the historical development of the Indian pharmaceutical industry was the ability of Indian firms to manufacture pharmaceuticals, as long as they bypassed patents held by Western MNCs by adopting different manufacturing processes. The TRIPS agreement closed this 'loophole', thereby expanding markets for MNCs at the expense of local pharmaceutical firms in developing countries. $^{19}$

Arguably, MNCs will oppose the formation of international regulatory regimes precisely because they solve international collective action problems and enable regulation. These agreements tend to raise final product prices, limit demand, and impose compliance costs on MNCs. As David Lake puts it, "the private actors prospering in the interstices of political authority are not leading the charge for supra-national entities designed to regulate their behavior more effectively." 20 However, this may not be true if regulatory regimes impose asymmetrical costs across firms. Thus, in formulating their political strategies, MNCs pay close attention not to regulation per se, but rather to the regulatory costs they bear in relation to their market competitors. Moreover, they are likely to consider carefully whether to undertake a political offensive individually or collectively. Trade associations have emerged as key vehicles for such collective political strategies, reducing the cost of political action. However, where asymmetrical costs of regulation offer opportunities for unilateral advantage, companies are less likely to act in concert.

To elaborate, regulatory regimes carry significant implications for competitiveness, as costs are imposed unevenly and new market opportunities could be created. In the case of ozone depletion, the major US producers of ozone depleting gases (CFCs) came to support an international agreement to reduce production. Dupont, the world's largest CFC producer, faced a stagnant domestic market due to unilateral regulation in the US and saw the substance becoming a low-margin commodity. ${ }^{21}$ Dupont had invested heavily in substitute chemicals prior to the treaty, anticipating that its dominant market position, extensive distribution channels, and expertise in chemical engineering would lead the company to gain a strong position in CFC substitutes. European producers, by

18. Rugman and Gestrin (1993).

19. Sell (2002).

20. Lake (1999) p. 46.

21. Parson (1993); Rothenberg and Maxwell (1997). 
contrast, opposed CFC controls because they enjoyed growing export markets, lacked domestic controls, and lagged in the development of CFC substitutes.

Regulation can create barriers to entry in a number of ways; regulated industries, such as hazardous waste, frequently have complex procedures for certifying new processes, thereby stabilizing existing technologies and protecting market incumbents. ${ }^{22}$ Compliance activities also constitute a relatively fixed cost that result in economies of scale favoring larger incumbents. ${ }^{23}$ Companies sometimes initiate private, voluntary mechanisms, such as the chemical industry's Responsible Care program, to raise public confidence, reduce the threat of governmental regulation, and discipline poor performers who might attract negative publicity and pressure for the whole industry. ${ }^{24}$ Some companies could gain relative advantage from regulations if they have lower compliance costs and are better situated to innovate. ${ }^{25}$ If companies have already adopted advanced technologies, they may wish to shape regulations to broaden the market for them or raise entry costs for rivals. ${ }^{26}$ A good example is the German insistence that the EU adopt some version of its "best available technology" clause for its Eco-Audit and Management System, an environmental governance code. Because German laws require German firms to adopt best available technology, German firms wanted their European competitors to face the same cost structures. Britain, on the other hand, generally adopts a more voluntaristic style of environmental governance and avoids policies that force specific technologies on its firms. Hence, British firms lobbied their government against agreeing to the German proposal. ${ }^{27}$

\section{Regime authority structure}

Regimes vary widely in the location of their monitoring, enforcement, and sanctioning authorities. These can be situated at the domestic, regional, or supranational levels, and rely on public or private mechanisms. It is frequently assumed that MNCs seek to escape from the regulatory efforts of domestic governments and social forces by establishing international governance structures beyond the reach of democratic accountability and pressures from labor and other social groups, which are primarily organized on a domestic basis. ${ }^{28}$ While MNCs have generally supported the establishment and expansion of international market enabling regimes such as the WTO and the MAI, MNCs have often fought to keep regulatory authority for environmental and social issues at the national level. The preferences of NGOs are frequently the inverse of MNCs; they tend to oppose the expansion of international market enabling regimes, but support international-level governance for regulatory regimes such as ozone depletion or labor rights.

22. Maloney and McCormick (1982).

23. Reinhardt (2000).

24. Garcia-Johnson (2000); Nash and Ehrenfeld (1997); Prakash (2000b).

25. Mitnick (1993).

26. Nehrt (1998).

27. Kollman and Prakash (2001).

28. Korten (1995). 
Preferences of MNCs for regime structures depend on their perceptions of their influence relative to NGOs and other protagonists in various fora. Levy and Egan, in a study of the climate change negotiations, have argued that the organizational, political, and discursive influence of US energy-related businesses was much greater domestically than in the international arena. ${ }^{29}$ The negotiations involved more than 140 countries, many of which were remote from the influence of US companies. The international institutions guiding the negotiations, particularly the scientific assessment bodies, had developed a degree of autonomy and legitimacy that provided some insulation from the interests of particular countries or industry sectors. Supranational organizations seeking to extend environmental and social regulation are frequently perceived to be more sympathetic to NGOs than to MNCs. In terms of principal-agent theory, it is likely to be much harder for firms acting as principals to make international organizations and foreign governments act as their agents. ${ }^{30}$ It is therefore not surprising that some companies fear the emergence of an international regulatory bureaucracy beyond the usual channels of influence. Moreover, if international economic integration does indeed weaken the autonomy and sovereignty of nation states and erode NGOs' access to decision-making at the national level, then MNCs will find that their leverage will increase at the national level. Even if internationalization is an incomplete and uneven process, the ideology of globalization and competitiveness seems to exert a disciplining effect on state managers and policy makers, producing the "competition state," whose primary goal is to be an attractive location for MNC activity. ${ }^{31}$

Despite MNCs' general antipathy toward international regulatory regimes, specific competitive considerations can mitigate this outlook. While efforts to coordinate social or environmental policies in international fora might sometimes lead to a costly upward harmonization of regulatory standards, MNCs aspiring to serve global markets often find a patchwork of national standards and regulations to be even more expensive, in terms of product adaptation, loss of economies of scale, and administrative expenses. Few MNCs pursue pure multidomestic strategies, which respond to local differences in taste, culture, and distribution channels, without also seeking some of the benefits of rationalization across markets. ${ }^{32}$ The desire for harmonization and economies of scale has clearly been one of the key economic drivers for the development of the governance structures of the EU, ${ }^{33}$ though weaker sectors, such as the European car industry, have sometimes sought national level regulations as a form of protectionism. $^{34}$

Internationally harmonized regulations can also serve to preempt local standards that are, in some instances, extremely strict. For example, the US automobile industry has been very keen to establish binding federal emission standards that would impose a constraint on states, particularly California and

29. Levy and Egan (1998).

30. Keim and Baysinger (1993).

31. Carnoy, Castells and Cohen (1993).

32. Bartlett and Ghoshal (1989).

33. Pollack and Shaffer (2001).

34. McLaughlin, Jordan and Maloney (1993). 
Massachusetts. Harmonized standards, even if not representing a lowest common denominator, are likely to be weaker than the level set by the most aggressive local authority. The Codex Alimentarius, for instance, developed under the auspices of the WTO, is an international set of safety standards for chemicals in foodstuffs that has been widely criticized for its laxity and opaque process.

MNC preferences for regime structures can also depend on the cost of engaging in negotiations in various arenas. The cost of international lobbying and bargaining efforts is not trivial, particularly for smaller companies. In a study by Getz of corporate political activity by companies involved in the ozone depletion issue, she found that only the largest and most profitable U.S. firms targeted international organizations. ${ }^{35}$ Getz argued that most firms would prefer to operate at the national level because that is where environmental laws are implemented and enforced, and most firms lack the financial resources and political sagacity to conduct international negotiations. Despite these concerns, the international arena could offer companies economies of scale in their political activities in two respects. First, MNCs might find that fewer resources are needed to resolve an issue in a single international forum than to negotiate the issue on a country-by-country basis. Second, an international forum offers MNCs the opportunity to share the costs of political activity with firms based in other countries. Indeed, Coen notes that while many companies have cut back on their government affairs budgets during the latter 1990s, they have increasingly turned to issue-specific international industry associations and alliances to share the costs and increase their leverage. ${ }^{36}$ Of course, cross-country institutional variations in the organization of labor and capital will significantly influence the propensities to use national-level associations as well as strategies employed to influence policy processes. ${ }^{37}$

Just as regimes can combine elements of market enabling and regulatory features, they can also exhibit complex authority structures. In many cases, the authority to monitor, enforce, and sanction are shared between domestic and supranational arenas. For example, the WTO provides a dispute resolution mechanism at the supranational level, but the decision on sanctions is taken at the domestic level. In the beef hormone case, the WTO ruled in favor of the US but the retaliatory tariffs imposed on EU products were decided solely by the US Trade Representative. In the climate change regime, supranational institutions conduct scientific assessments, negotiate country emission budgets, and establish broad guidelines for emission trading mechanisms, but each country is responsible for developing national mechanisms to control its emissions of greenhouse gases. ${ }^{38}$

Several authors have noted the rise of private sources of authority in international governance. Haufler has observed that self-regulation is particularly likely when companies face high risks of new government regulations, activist pressures threaten their reputation, and high asset specificity constrains strategic

35. Getz (1993).

36. Coen (1999).

37. Hillman and Keim (1995).

38. Grubb and Vrolijk and Brack (1999). 
options. ${ }^{39}$ Self-regulation is facilitated by high levels of information exchange, learning, and consensus within the industry. Industry codes and standards, such as the ISO 14000 environmental management standards, constitute private regulatory regimes but also become incorporated into governmental regulatory structures, creating complex hybrid forms. ${ }^{40}$ In disputes over commercial contracts, MNCs routinely require private arbitration as a condition of doing business ${ }^{41}$ - the recent dispute between Enron and the Government of Maharashtra, India, being a case in point. Importantly, in establishing some of these private regimes such as the Forest Stewardship Council, NGOs have been key actors.

\section{A bargaining approach to understanding international governance}

MNCs do not always succeed in securing the regimes they desire. This section examines how outcomes of negotiations over regime formation among MNCs, governments, and NGOs depend on the relative power of the actors and idiosyncrasies of the bargaining process. In the obsolescing bargaining model of the 1970s, MNCs wanted to maximize their share of financial gain, by keeping taxes and royalties paid to the host country low, and by gaining access to subsidies for capital investment and infrastructure development. In addition, MNCs were seen as desiring a predictable and stable environment, and autonomy from "arbitrary" governmental interventions in areas such as currency conversion, profit repatriation and local content requirements. These goals have not disappeared in the new bargaining over international governance structures. Indeed, the effort to establish the MAI and broaden the WTO to include services (GATS), intellectual property rights (TRIPS), and trade-related aspects of foreign investment (TRIMS), can be understood, at least in part, as an attempt to incorporate some of these objectives into a new set of ground-rules for MNC-host country bargaining. Rather than bargain with states deal-by-deal, however, some of the new multilateral trade and investment regimes institutionalize MNC positions by greatly reducing the ability of states to impose performance requirements, discriminate between domestic and foreign investors, or otherwise reduce the value of an investment. Building upon the obsolescing bargaining model, we suggest that the complexity and dynamic nature of bargaining processes, with multiple actors attempting to exert leverage through various sources of power, leads to somewhat indeterminate outcomes. ${ }^{42}$

The bargaining model of MNC-host country relations focused primarily on bilateral regulatory regimes with domestic locus of authority. This model was developed in the context of the polarized debate in the 1970s between those who saw foreign direct investment (FDI) as a manifestation of the growing power of multinational corporations and fundamentally antithetical to host country inter-

39. Haufler (2001).

40. Clapp (1998); Cutler, Haufler and Porter (1999); Prakash (2000a).

41. Mattli (2001).

42. Braithwaite and Drahos (2000). 
ests ${ }^{43}$ and those who argued that the power of MNCs had been exaggerated and their economic benefits ignored. ${ }^{44}$ The bargaining model represented a pragmatic approach in which the benefits of FDI to the host country would be contingent on the specific contractual arrangements of each deal. MNCs and host countries would bargain over the distribution of benefits from each instance of FDI, and the bargaining power of each side was determined by the possession of rare or unique assets. ${ }^{45}$ MNCs, for example, might offer certain technological and marketing capabilities, while host countries could control access to natural resources and local markets. ${ }^{46}$ Over a period of time, the shifting balance of power between the MNC and the host country would tend to make the original bargain obsolete, leading to some renegotiation of terms. ${ }^{47}$

In the three decades since Vernon laid the groundwork for the bargaining model, evolving global political and economic conditions require its revision. As Vernon himself later recognized, conflict over the potential value of FDI to host countries has by and large disappeared. ${ }^{48}$ Whether through conviction or coercion, developing countries have increasingly opened their economies to trade and inward investment. ${ }^{49}$ In part, this trend reflects the broader ideological shift towards open markets and deregulation. As tools of governance, market-enabling regimes had become as important as regulatory regimes. During the 1980s, scholars shifted their attention from concerns about MNC power toward the efficiency gains available in the internalized structure of the MNC. ${ }^{50}$ Intellectual and political challenges to the role of MNCs waned as the institutional bases for such perspectives weakened. In the new atmosphere, collaborative dimensions of state-MNC relations have received more attention than conflict. ${ }^{51}$

In the 1990s, however, the increased visibility of NGOs opposing unfettered globalization has renewed debates over the power of MNCs vis-à-vis other actors. NGOs have successfully added non-economic issues such as environmental standards to bargaining agendas that traditionally have focused on MNC-state distributional concerns. Thus, dyadic bargaining between states and MNCs has developed into multiparty bargaining among NGOs, governments and firms. A confluence of issues, from genetically modified organisms to sweatshops, has mobilized a new generation of activists and generated pressure for new modes of international governance that accord a more significant role to civil society. ${ }^{52}$ Governments and MNCs have increasingly granted NGOs a seat at the negotiating table, and consequently the strategies and tactics of NGOs influence the bargaining process over governance structures and processes. ${ }^{53}$

\footnotetext{
43. Barnet and Muller (1974); Evans (1979).

44. Gilpin (1975); Johnson (1970).

45. Vernon (1971).

46. Fagre and Wells (1982); Kobrin (1987).

47. Moran (1985).

48. Vernon and Spar (1990).

49. Dunning (1993); Strange (1993).

50. Dunning (1988); Hennart (1982).

51. Murtha and Lenway (1994).

52. O'Brien et al. (2000), Prakash and Kollman (2004).

53. Newell (2001), but see Clark et al. (1998).
} 
The revised bargaining model presented here reflects the emergence of a new, broader, terrain of contestation, one that relates to the very structures and processes of international governance. It seeks to examine both regulatory and market-enabling regimes. Eden has discussed the multifaceted nature of globalization and has identified three components in particular: the convergence of production, financial, and technological structures, the synchronization of national economies, and the interpenetration of flows of trade, investment, and technology.$^{54}$ Concurrent with this economic globalization, though less noted in the literature, is the growth of governance structures at regional and international levels that provide an institutional context of rules and norms for the global economy. Just as MNCs have been major agents of economic interdependence, they are interested and important actors in constructing the edifice of the new global polity. In doing so, they negotiate and bargain with a range of other actors, including home and host governments, NGOs, and existing international and supra-national organizations.

Despite the effort within regime theory to focus attention on the institutions of governance rather than governments, regime theory has been much criticized for its state-centered perspective,$^{55}$ and for its functionalist emphasis on reducing transaction costs and solving collective action problems. ${ }^{56}$ Only recently have scholars begun to take non-state actors more seriously as important agents in the processes of international governance. ${ }^{57}$ Peter Haas has pointed to the importance of "epistemic communities" of scientists as key agents in shaping environmental regimes, ${ }^{58}$ while some have looked more broadly to the role of global civil society and business. ${ }^{59}$

If regime theory has been too state-centered, then the neo-Gramscian historical materialist perspective in IR has placed too much emphasis on the power of capital in the global polity. ${ }^{60}$ In the process of forging a transnational hegemonic bloc dominated by MNCs, in alliance with internationally oriented state and NGO elites, national states are viewed as passively adapting to accommodate the demands of the new global economy. Robinson argues that national states are converted "into transmission belts and filtering devices for the imposition of the transnational agenda." ${ }^{\prime 1}$ Although Gramsci's concept of hegemony represents a negotiated consensus reflecting a historically specific balance of social forces, the rendition in the IR literature tends to be a top-down account in which national and global governance structures are determined by the economic needs of MNCs.

\footnotetext{
54. Eden (1993).

55. Litfin (1994); Strange (1993).

56. Keohane (1983); Young (1989).

57. Higgott, Underhill and Bieler (1999).

58. Haas (1992).

59. Cutler, Haufler and Porter (1999); Lipschutz (1992); Wapner (1995).

60. Cox (1987); van der Pijl (1984).

61. Robinson (1996) p. 19.
} 


\section{Characteristics of the bargaining terrain}

We outline here the key characteristics of the new bargaining terrain underlying the processes of regime formation. In doing so, we suggest a theoretical path that avoids the state-centrism of regime theory and the deterministic materialism of the neo-Gramscian approach, while building on insights from these two perspectives. It offers a bottom-up "micro-macro" approach ${ }^{62}$ in which regimes are the negotiated outcome of bargaining amongst MNCs, states, NGOs, and other actors. We draw on regime theory to view global governance as the development of norms, cognitive frames, as well as organizational infrastructure. We also note that regime characteristics vary on two critical dimensions: regime purpose and location of authority. Thus, not all regimes are mechanisms for equitable solutions to collective action problems.

The neo-Gramscian perspective places regime formation in the broader context of political contests between different groups of social actors in the global polity. Regime structures and processes therefore reflect the varying power, resources, and strategies of the various actors in these contests. Despite the substantial material resources possessed by MNCs, other actors also have considerable influence over regime-building processes, on account of their organizational capabilities and ability to resonate with particular ideological and cultural discourses. Moreover, as discussed subsequently, MNCs from different sectors and with different competitive positions rarely speak in one voice on issues of supranational governance, thereby creating political space for other societal actors to exploit these differences and push their agendas. The outcomes of these negotiations among host and home governments, business, and civil society, over a series of specific issue arenas, are constitutive of the emerging international system of governance, accounting for its untidy and uneven form.

In addition to examining both regulatory and market enabling regimes, our approach differs from the traditional bargaining model in three respects: the bargaining process involves multiple actors, these actors can draw upon multiple bases of power, and the bargaining process is dynamic, extended over time, and somewhat indeterminate.

\section{Multi-actor bargaining}

In the traditional bargaining model, negotiations were typically bilateral, between the MNC and the host government. Further, the old bargaining framework presumed the state to be a unitary actor negotiating as a single entity with a given set of interests. In our revised approach, bargaining is a multi-actor process among NGOs, states, firms, and international organizations. Indeed, even states may be represented by multiple authorities, such as departments of environment and state, with conflicting interests. Organizations representing labor, environmentalists, scientists and other elements of civil society have been particularly active in negotiations over environmental regimes, such as those for

62. Braithwaite and Drahos (2000). 
climate change, ${ }^{63}$ ozone depletion, ${ }^{64}$ and biodiversity, ${ }^{65}$ as well as for private codes of conduct regarding MNCs in developing countries. Even when not seated directly at the negotiating table, activist groups have exerted considerable influence through street demonstrations and through the dissemination of information; some have attributed the derailing of the MAI to the strategic use of the Internet by activist NGOs. ${ }^{66}$ Even the original Bretton Woods institutions, the World Bank and the International Monetary Fund, which were established through negotiations among a small number of states, have gradually been opening themselves to non-state influences. ${ }^{67}$

The implication of a multi-actor bargaining perspective is that governments and firms are now subjected to several influences, often exercised through traditional as well as non-traditional channels. Thus, firms and governments exercise less control over the bargaining process, and bargain outcomes are more uncertain. A broader range of goals is up for negotiation, and a more diverse set of norms and values are likely to be introduced. The result is a greater space for potential conflict, yet simultaneously more opportunities for opportunistic coalitions. One of the implications then is that it is difficult to find "pure" regime types: to satisfy diverse constituencies most regimes have both regulatory and market-enabling features. For example, to get sufficient support in the Congress for NAFTA, a market-enabling regime, President Clinton had to agree to incorporate certain regulatory features to win support from the environmentalists.

\section{Relative power}

In the traditional bargaining model, power was derived from the possession of unique assets, market access, and technologies. Indeed, the possession of firm-specific advantages provides the raison d'etre for MNCs to exist. ${ }^{68}$ Similarly, a country's power derives from its ability to offer access to large markets or valuable mineral resources. In the revised bargaining perspective, economic power is but one of several sources of leverage. Also, the power of MNCs now needs to be assessed relative to NGOs as well as host governments.

The power to frame debates within particular discursive and cultural contexts has increasingly been recognized as a key factor in the course of international negotiations. ${ }^{69}$ Negotiations over environmental regulatory regimes, for example, often revolve around contested claims concerning science. ${ }^{70}$ Industry has generally advocated for a "sound science" approach that requires a high burden of proof before regulatory action is taken, while environmental NGOs and some

63. Newell (2000)

64. Litfin (1994).

65. Levidow (1999).

66. Kobrin (1998).

67. Scholte (2000).

68. Dunning (1988).

69. Haas (1996); Litfin (1994).

70. Jasanoff (1990). 
European governments have urged adoption of the "precautionary principle." Keohane and Nye have used the term "soft power" to describe:

[...] the ability to get desired outcomes because others want what you want. It is the ability to achieve goals through attraction rather than coercion. It works by convincing others to follow or getting them to agree to norms and institutions that produce the desired behavior. Soft power can rest on the appeal of one's ideas or culture or the ability to set the agenda through standards and institutions that shape the preferences of others. ${ }^{71}$

The Gramscian concept of hegemony similarly rests on a form of "soft power" that generates legitimacy and consent by projecting intellectual and moral leadership and a sense of common interests. A key implication of the discursive aspect of power is that actors' interests and preferences are not fixed by structural circumstances, but can be shifted by framing issues in particular ways. Thus, firms can establish new alliances not merely through traditional means of offering material incentives but also by providing information and new framings for issues.

Organizational structures and capacity also serve as a critical resource in the exercise of power. Murtha and Lenway have discussed how governments can deploy their organizational capabilities and political institutional structures in a strategic manner to influence MNC investment behavior. ${ }^{72}$ NGOs are frequently able to compensate for their lack of material resources by coordinating their lobbying and information dissemination and by appealing to moral principles. Indeed, many scholars have argued that an embryonic global civil society, which is somewhat autonomous from the state-centric system, is starting to emerge. ${ }^{73}$

MNCs most commonly coordinate their input into international negotiations through various sector-specific industry associations, but also form transnational issue-specific groups around significant issues. ${ }^{74}$ Despite diverging perspectives on regulatory issues among MNCs from different sectors and countries, organizations such as the International Chamber of Commerce and the Trans-Atlantic Business Dialogue have been establishing working groups on specific issues to improve the level of international and cross-sector coordination as well as to fill in the "expertise gap." Such issue specific and/or industry specific coalitions are important in strengthening MNCs bargaining power in relation to governments. The emergence of several new bases of power implies that the outcomes of the bargaining process is now critically influenced by bargaining strategies, especially regarding how actors are able to project their perspective in the media. This requires MNCs to develop local as well as global political competencies, as they are trying to fend off challenges at multiple levels. Again, such indeterminacies and multiple bases of power lead to regimes that do not correspond to ideal types, but rather incorporate both regulatory and market-enabling features.

71. Keohane and Nye (1998) p. 86.

72. Murtha and Lenway (1994).

73. Florini (2000); Lipschutz (1992); Rosenau (1992).

74. Coen (1999). 


\section{Bargaining process dynamics}

The traditional bargaining framework suggested that relative power between the MNC and the host country might shift over time, leading to pressure for renegotiations. Most bargaining theory proponents argued that MNCs lost the key bargaining chip of capital mobility once an investment was made, and that host governments gained power over time as local personnel gained technical expertise and managerial capabilities. ${ }^{75}$ Critics of this view claimed that continued innovation by MNCs, control of export markets, multi-lateral financing arrangements, alliances with host country elites, and the dependence of host countries on private sources for future investments, would constrain and even diminish host country autonomy and power. ${ }^{76}$ Thus the bargaining framework did embody a dynamic element that considered shifts in power and the pressure to revise agreements. Nevertheless, each bargain was a discrete event occurring at a specific point in time; if shifts in power and outcomes were analyzed for two bargaining events, this was an exercise in comparative statics, and linkages across separate bargaining domains were rarely examined.

In the revised perspective, we view bargaining as an ongoing path-dependent process, sometimes extended over many years. This is particularly apt for bargaining over institutions of governance. Clearly, market-enabling regimes such as the WTO and regulatory regimes such as that for climate change have evolved over many rounds of negotiation, each of which built on the norms, rules, institutions, and collective experience developed during previous rounds. Linkages also exist across regimes. For example, the institutional arrangements for providing scientific assessments to the ozone negotiations became the reference point for the climate regime. More broadly, the market-based norms of dominant regimes such as the WTO have informed the premises of regulatory regimes. Moreover, it is apparent that the process of negotiation itself exposes companies to new institutional settings and viewpoints, which have the potential to shift corporate perceptions of their interests. For example, during the climate regime negotiations, MNCs such as BP and Volkswagen shifted their positions from opposition toward support, as they developed the view that environmental and business goals can be compatible. ${ }^{77}$

In the traditional FDI bargaining framework, the relative power of each side determined the division of surplus from the investment between the parties. ${ }^{78}$ In our perspective, the complex and dynamic nature of negotiations combined with strategic behavior by actors makes the outcome somewhat indeterminate, and the most obviously powerful actor does not always win. ${ }^{79}$ Outcomes are thus a function of the specific processes and context of each regime. Oran Young argues that "institutional bargaining almost always involves a major element of

75. Moran (1985).

76. Evans (1979); Gereffi (1985).

77. Levy and Rothenberg (2002).

78. Moon and Lado (2000).

79. This would appear to make it difficult to test our bargaining model empirically. One approach might be to propose that the complexity of negotiations, in terms of number of parties and issue linkages, reduces the importance of material resources in determining outcomes. 
integrative bargaining in contrast to distributive bargaining. ${ }^{80}$ In other words, regime formation is not a zero-sum game, and, as a result, the control of economic and material resources is less important in determining the outcome. Rather, negotiations require a great deal of strategic positioning and bargaining skill, in which actors with less power in the traditional sense of material resources can sometimes outmaneuver their rivals.

\section{Conclusions}

This paper outlines an approach for understanding the role of MNCs in international governance that is based on a typology of regime types that is useful for analyzing MNC preferences, and that builds on the bargaining model of foreign direct investment (FDI). In our characterization, regimes vary in two key dimensions, the goal of the regime, which can be market enabling or regulatory, and the location of authority. However, such ideal types seldom exist and most regimes incorporate both market enabling and regulatory features to satisfy diverse constituencies. In general, MNCs tend to support the creation of market enabling regimes at the international level, and, if they are under pressure to accede to social or environmental regulation, prefer that the locus of authority be national and private. However, there are many instances where these generalizations do not hold, and MNCs assess their preferences in light of their relative influence in various arenas, the costs of political participation, and competitive considerations specific to each regime and industry.

Just as in the original bargaining model, MNCs in international governance are neither omnipotent ogres nor gentle giants pursuing the common interest; rather, they bargain with states, NGOs, and other actors over the form and structure of particular international agreements and regimes. We argue that the emergent institutions of global governance represent the outcome of a series of negotiations; the preferences and power of MNCs vary across issues and sectors, and from one negotiating forum to another, which accounts for the uneven and fragmented nature of the resulting system. Our conceptualization of bargaining over governance structures differs from the traditional framework in that it recognizes the multi-party nature of negotiations, multiple sources of power, and the complexity and dynamic nature of the bargaining process. The resultant indeterminacy of outcomes suggests that while MNCs are powerful actors, they do not always succeed in imposing their preferred regime type. Moreover, regimes are shaped by the particular strategies of MNCs operating in specific industry and competitive contexts, leading to idiosyncratic outcomes that are at variance with predictions based on simple hypotheses such as the decline of the regulatory state or the race-to-the-bottom.

We have chosen to focus on the preferences and power of MNCs. Future research could build upon this approach to examine the positions of states, international institutions and non-state actors. Overall, it may well be possible to discern a trend toward private sources of authority and an increase in the power of MNCs relative to states and NGOs, but an endpoint "when corporations rule

80. Young (1994) p. 127. 
the world" 81 is highly unlikely. NGOs and states are also building their capacities to coordinate their activities and act effectively in international arenas, ensuring that continued contestation would be the one reliable feature of international governance structures.

\section{Bibliography}

Barnet, Richard J. and Ronald E. Muller. 1974. Global Reach: The Power of the Multinational Corporations. New York: Simon \& Schuster.

Baron, David P. 1995. 'Integrated Strategy: Market and Nonmarket Components.' California Management Review 37(2): 47-65.

Bartlett, Christopher and Sumantra Ghoshal. 1989. Managing across Borders: the Transnational Solution. Boston, MA: Harvard Business School Press.

Braithwaite, John and Peter Drahos. 2000. Global Business Regulation. Cambridge: Cambridge University Press.

Carnoy, Martin, et al., editors. 1993. The New Global Economy in the Informational Age. University Park, PA: Pennsylvania State University Press.

Chandler, Clay. 2001. 'AIG Dispute keeps China out of WTO.' Washington Post.

Clapp, Jennifer. 1998. 'The Privatization of Global Environmental Governance: ISO 14000 and the Developing World.' Global Governance 4: 295-316.

Clark, A. M., E. J. Friedman, and K. Hochstetler. 1998. 'The Sovereign Limits of Global Civil Society.' World Politics 51: 1-35.

Coen, David. 1999. 'The Impact of U.S. Lobbying Practice on the European Business-Government Relationship.' California Management Review 41(4): 27-44.

Cox, Robert W. 1987. Production, Power, and World Order. New York: Columbia University Press.

Cutler, Claire A., et al., editors. 1999. Private Authority and International Affairs. Albany, NY: SUNY Press.

Dunning, John. 1988. Explaining International Production. Boston, MA: Unwin Hyman.

Dunning, John H. 1993. 'Governments and Multinational Enterprises: from Confrontation to Co-operation? In Multinationals in the Global Political Economy, edited by Eden, Lorraine and Evan Potter. New York: St. Martins.

Eden, Lorraine. 1993. Bringing the firm back in: multinationals in the international political economy. In Multinationals in the Global Political Economy, edited by Eden, Lorraine and Evan Potter. New York: St. Martins.

Eden, Lorraine and Maureen Appel Molot. 1993. 'Continentalizing the North American Auto Industry.' In The Political Economy of North American Free Trade, edited by Grinspun, Ricardo and Maxwell A. Cameron. New York: St. Martin's Press.

Evans, Peter. 1979. Dependent Development: the Alliance of Multinational, State, and Local Capital in Brazil. Princeton, NJ: Princeton University Press.

Fagre, N. and Louis T. Wells. 1982. 'Bargaining power of multinationals and host governments.' Journal of International Business Studies 13: 9-23.

Florini, Ann M. 2000. 'Who Does What? Collective Action and the Changing Nature of Authority. In Non-State Actors and Authority in the Global System, edited by Higgott, Richard A., Geoffrey R. D. Underhill, and Andreas Bieler. London: Routledge.

Garcia-Johnson, Ronnie. 2000. Exporting Environmentalism. Cambridge, MA: MIT Press.

Gereffi, Gary. 1985. 'The Renegotiation of Dependency and the Limits of State Autonomy in Mexico.' In Multinational Corporations: the Political Economy of Foreign Direct Investment, edited by Moran, Theodore. Lexington, MA: D.C. Heath.

Getz, Kathleen A. 1993. 'Selecting Corporate Political Tactics.' In Corporate Political Agency, edited by Mitnick, Barry M. Newbury Park, CA: Sage.

Gilpin, Robert. 1975. US Power and the Multinational Corporation. New York: Basic Books.

Grubb, Michael, et al. 1999. The Kyoto Protocol: a Guide and Assessment. London: RIIA/Earthscan.

Haas, Peter M. 1992. 'Banning Chlorofluorocarbons: Epistemic Community Efforts to Protect Stratospheric Ozone.' International Organization 46(1): 193-212.

81. Korten (1995). 


\section{Multinational Corporations in Global Governance}

Haggard, Stephan and Beth A. Simmons. 1987. 'Theories of International Regimes.' International Organization 41: 491-517.

Haufler, Virginia. 2001. 'A Public Role for the Private Sector: Industry Self-Regulation in a Global Economy. Washington, DC: Carnegie Endowment for International Peace.

Hennart, Jean-Francois. 1982. A Theory of Multinational Enterprise. Ann Arbor, MI: University of Michigan.

Higgott, Richard, et al., editors. 1999. Non-State Actors and Authority in the Global System. London: Routledge.

Hillman, Amy and Gerald Keim. 1995. 'International variation in the business-government interface: institutional and organizational considerations.' Academy of Management Review 20(1): 193-214.

Jasanoff, Sheila. 1990. The Fifth Branch. Cambridge, MA: Harvard University Press.

Johnson, Harry G. 1970. 'The efficiency and Welfare Implications of the International Corporation.' In The International Corporation, edited by Kindleberger, Charles. Cambridge, MA: MIT Press.

Keim, Gerald D. and Barry D. Baysinger. 1993. 'The Efficacy of Business Political Activity.' In Corporate Political Agency, edited by Mitnick, Barry M. Newbury Park, CA: Sage.

Keohane, Robert. 1983. 'The Demand for International Regimes.' In International Regimes, edited by Krasner, Stephen D. Ithaca, NY: Cornell University Press.

Keohane, Robert O., et al. 1993. 'The Effectiveness of International Environmental Institutions.' In Institutions for the Earth: Sources of Effective International Environmental Protection, edited by Haas, Peter M., Robert O. Keohane, and Marc A. Levy. Cambridge, MA: MIT.

Keohane, Robert O. and Joseph S. Nye. 1998. 'Power and Interdependence in the Information Age.' Foreign Affairs 77(5): 81-93.

Kobrin, Stephen. 1998. 'The MAI and the Clash of Globalization.' Foreign Policy (Fall): 97-109.

Kobrin, Stephen J. 1987. 'Testing the Bargaining Hypothesis in the Manufacturing Sector in Developing Countries.' International Organization 41: 609-638.

Kolko, Gabriel. 1963. Railroads and Regulation: 1877-1916. Princeton, NJ: Princeton University Press.

Kollman, Kelly and Aseem Prakash. 2001. 'Green by choice?: Cross-National Variations in Firms' Response to ISO 14001 and the EMAS.' World Politics 53: 399-430.

Korten, David C. 1995. When Corporations Rule the World. West Hartford, CT: Kumarian Press.

Krasner, Stephen. 1983. 'Structural Causes and Regime Consequences: Regimes as Intervening Variables.' In International Regimes, edited by Krasner, Stephen. Ithaca, NY: Cornell University Press.

Lake, David A. 1999. 'Global Governance: a Relational Contracting Approach.' In Globalization and Governance, edited by Prakash, Aseem and Jeffrey A. Hart. London: Routledge.

Levidow, Les. 1999. 'Regulating Bt maize in the United States and Europe: A Scientific-Cultural Comparison.' Environment 41(10): 10-23.

Levy, David L. 1997. 'Lean Production in an International Supply Chain.' Sloan Management Review 38(2): 94-102.

Levy, David L. and Daniel Egan. 1998. 'Capital Contests: National and Transnational Channels of Corporate Influence on the Climate Change Negotiations.' Politics and Society 26(3): 337-361.

Levy, David L. and Daniel Egan. 2000. 'Corporate Political Action in the Global Polity: National and Transnational Strategies in the Climate Change Negotiations.' In Globalisation and Non-State Actors, edited by Higgott, Richard, Geoffrey Underhill, and Andreas Beiler. London: Routledge.

Levy, David L. and Sandra Rothenberg. 2002. 'Heterogeneity and Change in Environmental Strategy: Technological and Political Responses to Climate Change in the Automobile Industry.' In Organizations, Policy and the Natural Environment: Institutional and Strategic Perspectives, edited by Hoffman, Andrew and Marc Ventresca. Stanford, CA: Stanford University Press.

Lipschutz, Ronnie D. 1992. 'Reconstructing World Politics: the Emergence of Global Civil Society.' Millenium 21(3): 389-420.

Litfin, Karen T. 1994. Ozone Discourses: Science and Politics in Global Environmental Cooperation. New York: Columbia University Press.

Maloney, Michale T. and Robert E. McCormick. 1982. 'A Positive Theory of Environmental Quality.' Journal of Law and Economics 25(1): 99-123.

Mattli, Walter. 2001. 'Private Justice in a Global Economy.' International Organization 55: 919-947.

McLaughlin, Andrew, et al. 1993. 'Corporate Lobbying in the European Community.' Journal of Common Market Studies 31(2): 191-212.

Mitnick, Barry M. 1993. 'The strategic uses of regulation-and deregulation.' In Corporate Political Agency, edited by Mitnick, Barry M. Newbury Park, CA: Sage. 


\section{David L. Levy \& Aseem Prakash}

Moon and Lado. 2000. 'MNC-Host Government Bargaining Power Relationship: a Critique and Extension Within the Resource-Based View.' Journal of Management 26(1): 85-117.

Moran, Theodore H., editor. 1985. Multinational Corporations: the Political Economy of Foreign Direct Investment. Lexington, MA: Lexington Books.

Murtha, Thomas P. and Stephanie Ann Lenway. 1994. 'Country Capabilities and the Strategic State: How National Political Institutions Affect Multinational Corporations' Strategies.' Strategic Management Journal 15: 113-129.

Nash, Jennifer and John Ehrenfeld. 1997. 'Codes of Environmental Management Practice: Assessing their Potential as a Tool for Change.' Annual Review of Energy and Environment 22: 487-535.

Nehrt, Chad. 1998. 'Maintainability of First Mover Advantages when Environmental Regulations differ between Countries.' Academy of Management Review 23(1): 77-97.

Newell, Peter. 2000. Climate for Change: Non-State Actors and the Global Politics of the Greenhouse. Cambridge: Cambridge University Press.

Newell, Peter. 2001. 'Environmental NGOs, TNCs, and the Question of Governance.' In The International Political Economy of the Environment, edited by Stevis, Dimitris and Valerie J. Assetto. Boulder, CO: Lynne Rienner.

O’Brien, Robert, et al. 2000. Contesting Global Governance: Multilateral Economic Institutions and Global Social Movements. Cambridge: Cambridge University Press.

Parson, Edward A. 1993. 'Protecting the Ozone Layer.' In Institutions for the Earth: Sources of Effective International Environmental Protection, edited by Haas, Peter M., Robert O. Keohane, and Marc A. Levy. Cambridge, MA: MIT Press.

Pollack, Mark A. and Gregory C. Shaffer, editors. 2001. Transatlantic Governance in the Global Economy. Rowman and Littlefield.

Prakash, Aseem. 2000a. 'Responsible Care: an Assessment.' Business and Society 39: 183-209.

Prakash, Aseem. 2000b. Greening the Firm. Cambridge: Cambridge University Press.

Prakash, Aseem and Kelly Kollman, 2004. 'Biopolitics in the US and the EU: A race to the bottom or convergence to the top?' International Studies Quarterly 47(4): 609-633 (forthcoming December 2003).

Reinhardt, Forest. 2000. 'Global Climate Change and BP Amoco.' Harvard Business School Case Study.

Robinson, William. 1996. 'Globalization: Nine Theses on our Epoch.' Race and Class 38(2): 13-31.

Rosenau, James N. 1992. 'Governance, Order, and Change in World Politics.' In Governance without Government: Order and Change in World Politics, edited by Rosenau, James N. and Ernst Otto Czempiel. Cambridge: Cambridge University Press.

Rothenberg, Sandra and James Maxwell. 1997. 'Industry Response to the Banning of CFCs: Mapping the Paths of Technological Change.' Technology Studies 4(2).

Rugman, Alan M. and Michael Gestrin. 1993. 'The Strategic Response of Multinational Enterprises to NAFTA.' Columbia Journal of World Business 28(4): 18-29.

Scholte, Jan Aart. 2000. 'In the Foothills: Relations between the IMF and Civil Society.' In Non-State Actors and Authority in the Global System, edited by Higgott, Richard A., Geoffrey R. D. Underhill, and Andreas Bieler. London: Routledge.

Sell, Susan K. 2002. Private Power, Public Law. Cambridge: Cambridge University Press.

Stigler, G. 1971. 'The Theory of Economic Regulation.' Bell Journal of Economics 2: 3-21.

Strange, Susan. 1993. 'Big Business and the State.' In Multinationals in the Global Political Economy, edited by Eden, Lorraine and Evan Potter. New York: St. Martins.

Strange, Susan. 1996. The Retreat of the State: the Diffusion of Power in the World Economy. Cambridge: Cambridge University Press.

van der Pijl, Kees. 1984. The Making of an Atlantic Ruling Class. London: Verso.

Vernon, Ray. 1966. 'International Investment and International Trade in the Product Cycle.' Quarterly Journal of Economics 80: 190-207.

Vernon, Raymond. 1971. Sovereignty at Bay: the Multinational Spread of U.S. Enterprises. New York: Basic Books.

Vernon, Raymond and Debora Spar. 1990. Beyond Globalism: Remaking American Foreign Policy. New York: Macmillan.

Wapner, Paul. 1995. 'Politics beyond the state: environmental activism and world civic politics.' World Politics 47: 311-340.

Young, Oran R. 1989. International Cooperation: Building Regimes for Natural Resources and the Environment. Ithaca, NY: Cornell University Press.

Young, Oran R. 1994. International Governance: Protecting the Environment in a Stateless Society. Ithaca, NY: Cornell University Press. 